UDC 811.111:81'42

DOI https://doi.org/10.32841/2409-1154.2020.46-2.4

Makhachashvili R. K.,

ORCID ID: 0000-0002-4806-6434

Doctor of Philological Sciences, Associate Professor, Head of the Department of Romance Languages and Typology Borys Grinchenko Kyiv University

\author{
Semenist I. $V$., \\ ORCID ID: 0000-0002-0847-8856 \\ Ph.D. in History, \\ Head of the Department of Oriental Languages and Translation \\ Borys Grinchenko Kyiv University
}

\title{
ONTOLOGICAL PREMISES OF GLOBAL INNOVATIVE LOGOSPHERE OF COMPUTER BEING STRUCTURE (BASED ON EUROPEAN AND ORIENTAL LANGUAGES)
}

Summary. The paper is devoted to the ontological premises of comprehensive structuring of global innovative linguistic sphere of modern digital technologies (Global innovative logosphere of computer being as construed by the transformative neological strata of modern European and Oriental languages of international communication). The macrostructure of the Global innovative logosphere of computer being is identified as the generality of linguistic innovations of globalized European and Oriental languages in the systemic semantic unity of their reference correlation with the substantive (ontological, epistemic, anthropological) dimensions and elements of computer reality. The integration of the macro level of the global innovative computer logosphere is coordinated by the spectrum of its specific characteristics and is realized, first, due to the significant coordination of elements of internal and external form of this logosphere and signs of substantive and substrate originality of computer being as a whole; secondly, due to the phenomenological correlation of the elements of the internal and external form of the innovative computer logosphere and various types of structural elements of the computer being (ontological, epistemic and anthropological respectively), exhaustive, super-dense innovative verbalization of which determines the differential specificity of the studied logosphere. The microstructure of Global innovative computer logosphere is formed by the generality of discrete language units of the corresponding reference affiliation in the set of their formative and semantic features. The integration of the innovative computer logosphere is ensured by the configurative isomorphism of taxonymic (ontological, epistemic, anthropological) and operational mechanisms of integration of the macrostructure of the innovative computer being and taxonymic and operational mechanisms of integration of its external (formative) microstructure. The ontological denotatum in the structure of the ICTs content plane determines the symbolic specificity of the term as an integer of the macro- and micro-level structures of the Global innovative computer logosphere. Qualitative and quantitative characteristics, features and properties of the integrative structure of the innovative computer logosphere are informed by its dynamics on the macro and micro levels.

Key words: global innovative logosphere, computer being, innovative computer terminos, European languages, Oriental languages.
Problem statement and state-of-the-art review. Theoretical problems of complex, holistic, multidimensional modelling of reality and its separate spheres (one of which within linguistic studies of the XX - XXI centuries is the sphere of development and update of computer technologies) are directed by the deterministic interaction of objects, signs of their reception and interpretation (in the field of individual and collective consciousness), embodiment, consolidation and retransmission of the results of interaction of these systems of features.

At the turn of the XX - XXI centuries as an essential product of civilization, Computer reality has been gradually separated into an independent existential whole, within which electronic and digital media, in particular, serve not only as a means of transmitting information or interaction, but fulfill their own world-building, sense-building and, consequently, logogenerative potential [7]. Computer Being - CB hereon - (the term introduced by V.A. Kutyr'yev [21; 22], M. Heim [8]) is a complex, integrated, multi-dimensional sphere synthesis of reality, human experience and activity, mediated by contemporary digital and information technology and is an object of study of a wide range of academic branches - philosophy of modern humanities, psychology, sociology, cultural studies, etc. $[1 ; 4 ; 5 ; 14]$.

In this regard, the fundamental dimension of being (as synonymous with the latter "reality", "realm" and "world" can be used) $[3 ; 5 ; 10]$ is defined as a heterogeneous hyperonymic concept that can summarize the multidimensional features of the world order:

- the world that really exists and is subject to direct perception;

- a world that is not subject to direct reception, but exists in reality;

- a world that is imaginary, unreal (for example the ideal, mythological images);

- reality, which exists objectively, regardless of human consciousness (nature, objective physical laws of the world order, space-time dimensions);

- the general way of life of humankind, society, culture, civilization.

Thus, the Computer Being dimension is understood as a fundamental ontological parameter that exists outside the scope of human 
mind and is involved in the perceptual field regardless of the will of the subject of cognition.

Conditions for the development of modern globalization civilization determine the expansion and refinement of the paradigm of views on the theoretical principles of determining the groundwork and characteristics of the consolidation of the world order, its perception in culture, collective social consciousness and natural language.

The intellectualization of modern global culture determines a qualitatively new approach to understanding the processes of parallel development of human activities and cognitive (intellectual) experiences. That is the origin and methodological premise of the concept of "noosphere". The noosphere is defined as the current stage of development of the biosphere, associated with the emergence of humanity in it $[6 ; 9]$, and is interpreted as part of the planet and planet ambient with traces of human activity.

Given the definite unity of nature and culture (in their interaction) there are two stages determined in the development of the noosphere $[1 ; 7 ; 8 ; 15 ; 19]$ :

1) noosphere stage in its development, in the process of natural development, since the emergence of humans;

2) noosphere that is consciously improving joint efforts of people in the interests of humanity as a whole and each individual separately.

Among its components noosphere as a consolidated model of the universe incorporates:

- Anthroposphere (a set of people as living organisms, their activities and achievements);

- Sociosphere (a set of social factors and relations specific to the stage of development of society and its interaction with nature);

- Technosphere (a set of artificial objects, man-made and natural objects, changed as a result of human activity).

Given the context outlined transformation of initial position awareness of the principles and foundations of the universe integrated modeling, we note that at the turn of the XXI century modern computer technology as part of the technosphere (and respectively - the noosphere) take up more space in the public consciousness and functional activity of mankind.

The integral real component of the Noosphere is identified as the Technosphere - a set of artificial objects (technologies) created by the humankind, and natural objects changed as a result of technological activity of humankind [8; 11]. In turn, Computer Being (computer reality, cyberspace) is a complex, multidimensional, interdisciplinary sphere of synthesis of reality, human experience as represented through natural language and activity mediated by the latest digital and information technologies; technogenic reality, a component of the technosphere of existence.

Objective. The paper overall objective is the inquiry into the ontological permises of comprehensive structuring of global innovative linguistic sphere of modern digital technologies (global innovative logosphere of computer being as construed by the transformative neological strata of modern European and Oriental languages of international communication).

The objective hypothesis of the study is that the typological characteristics of innovative logosphere of computer being as a macro-object of a phenomenological investigation determine the specificity of static configuration and dynamic interaction of formal and substantive constituents of its microstructure. Around 4000 of speech and linguistic units - innovations that relate to multi-substrat areas, objects and phenomena of computer being - in usage serve as research empirical database, selected by canvas sampling out of con- ventional lexicographic sources, specific registers of English, Italian, Spanish, French, Mandarin Chinese and Japanese lexicographic innovations in electronic format and periodicals of the timespan from 1997 to 2021. (Note that within the procedural network analysis, but beyond the quantitative calculation of the sample retained are projected and potential linguistic units that are updated based on structural and semantic models of unlimited productivity within the English innovative computer logosphere, structurally and functionally extrapolated on other globalized languages).

Findings. As an essential product of civilization, modern computer reality has been isolated into an independent existential whole. It limits the electronic media serve not only as a means of transmitting information or interaction, but discover their own world-building, sense-building, and, consequently, linguogenerative potencial. Given the conceptual identification system of ontho-mental and linguistic-mental complex structures to determine reality constructs, computer being and its innovative linguistic shell can be located within the set of the following notional coordinates:

- A specific type of substance - material and ideal reality together of all forms of development - being;

- A zone of integrable anthropogenesis;

- Implementation environment for "post-humanistic" trends of anthropogenesis;

- A segment of the noosphere (the technosphere);

- A system of multi-level, countervailing social relations sociosphere.

- A psychosomatic and emotional plane,

- A sphere of spiritual experience

- Worldview, model of the world, picture of the world.

The logocentric approach to integrative research directions, mechanisms, ways and means of the digital vocabulary of modern globalized languages provides a generalized in-depth understanding of the phenomenological nature of linguistic reality encoding processes, linguistic recreation and mechanisms of neologozation, categorization, language reference, significative correlation, respectively.

The logosphere is perceived as a synthetic linguophilosophical concept that means: 1) a multitude of speech units that are the phenomenologically exhaustive implementations of abstract (substant, conceptual) and empirical (factual, objective) elements of different areas of life [19]; 2) integrable area of mind-speech continuum of a (linguistic) culture in general and specific (linguistic) cultures in particular [24].

Parameterization principles of a concept of "logos" in the paradigm of the humanities in general, linguophilosophy, and linguistics - in particular, allow to identify the features of logosphere as a complex object system pertaining the following parameters:

- Ubiquity (inclusiveness);

- Ontocentrizm;

- Integrativity;

- Automorphism;

- Normativity;

- Lingual substantiality;

- Phenomenology of thesaurus units;

- Information-capacity;

- Referential and semiotic isomorphism of the referent and meaning.

Through the fragmented set of qualitative features, logosphere is tangent to the concepts of complex system replicas of linguistic-mental outlook, such as: 
- Model of the world / world view (inclusive, integrative, self-identity);

- Language picture of the world (phenomenology of linguistic constituents - the ability to summarize and signify objects of reality);

- Noosphere (onthotsentrism, info-capacity).

For the listed set of features the integral notion of logosphere stands as a semantic synthesis of these concepts (see figure 1):

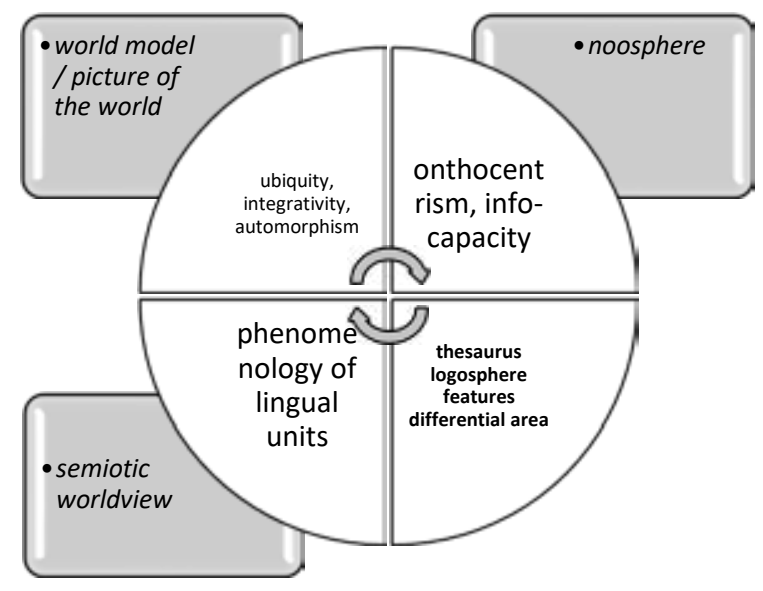

Figure 1. Global innovative logosphere integral and differential features model

It is appropriate to separate configuration and parameterization of a specified macrophenomenon of linguistic research - global innovative computer logosphere. Thus, the network innovation and relevant subsystems in computer logosphere (multidimensional, complex, dynamic system) is the most comprehensive quantitative and qualitative terms of language representation of the linguistic actualization of being, determined by a number of qualifying conditions of its emergence, existence and development [12], including:

1) exhaustive synchronization process of the object, phenomenological and anthropological field of computer being and development processes of the cyberspace meta-language;

2) exhaustive output of parameterization isomorphism of ontological (substance phenomenological), anthropic and digitized structures of reality;

3) flexibility, adaptability and dynamic potential of the vocabulary of the modern languages (heavily influenced by English global hegemony) in correlation with the ICT sphere (that is fulfilled, in particular through info-capacity, sign hybridization, the evolution of the basic ontological and functional features of neologisms in relevant areas).

In view of the foregoing, the Global innovative computer logosphere (GICL) is defined as:

a) a syncretic, consolidated within its semantic scope, plurality of verbal units that are the asymptotically (i.e. in unlimited approximation) exhaustive embodiments of substantive and factual elements of modern computer being.

b) as a vertically integrated at the macro and micro levels plurality of ICT thesaurus, its typological specificity being the relatively exhaustive phenomenological correlates of multi-substrat elements of computer being.

The specific differential features of GICL as a linguistic-ontological, linguistic-phenomenological object are:
- Normativity - arising from the parametric features of the concept of "logos" - (while maintaining the characteristics of dynamic variation and logosphere);

- Lingual substantivity - phenomenological status of verbal language signs membranes in reality;

- The principle of isomorphism of the signified and meaning.

The outline of each separate national (English, American, Iberoamerican, Asian) logosphere in synchrony within this study is positioned as an Innovative National Logosphere. Innovative English logosphere itself (multidimensional, of complex, dynamic system) is a kind of "test-ground" for linguistic actualization of reality. That is, linguistic (lexical-semantic) representation of new modes of reality exists within reach of the human mind, and therefore is subject to immediate perception and comprehension.

It is considered appropriate to separate configuration and parameterization of a specified macrophenomenon of linguistic research Global innovative computer being logosphere. Thus, the network innovation and relevant subsystems in modern European and Oriental Languages, the Global innovative computer being logosphere (multidimensional, complex, dynamic system) is the most comprehensive quantitative and qualitative mode of language representation of the universe "test site" for linguistic actualization of being mediated and informed by digital technologies development. Thus, linguistic representation of new modes of computer reality exists within reach of the human mind, and therefore is subject to direct perception and understanding (as opposed to reality as such, lingual ontogenesis of which, according to historical data paradigms and linguistic sciences can only be conditionality reconstructed by linguistic methods).

Given signs of the logosphere as a specific ontological and linguistic-semiotic object, we postulate to distinguish the following substantial characteristics of Global innovative computer logosphere (GICL):

- The ability to synthesize substances at their own attributes, parameters and properties of ontological objects and phenomena and innovative verbal units, respectively;

- Ability for an asymptotic (very close to exhaustive) implementation of the substantive and factual elements of modern computer being at their own substance as a whole and at the level of substantial characteristics of discrete verbal units that constitute the relevant innovation logosphere.

- Exhaustive semantic, formal and constructive density of implementation (reveal) of substantive and factual elements of modern computer being in the ontological, epistemological and anthropological plane.

Consequently, Global innovative computer logosphere (GICL) is understood as a vertically integrated at the macro and micro levels plurality of lingual innovations of European and Oriental languages, which in its typological specificity is a relatively exhaustive phenomenoogical correlate of multisubstrat elements of computer realm (figure 2 ).

From the above system of parametric characteristics of Global innovative computer logosphere macrostructure it is evident that the principle of hierarchical abstraction correlation powers its integrative macrostructure within the conceptual dyad substance : substrate. In this case, the substance is identified as an objective reality in terms of the internal unity of all forms of its manifestation and self-development [16]. The term "substrate" in turn, denotes the simplest structure or formation [25], which remains stable, unchanged under any transformation of the object and determines its specific properties. 


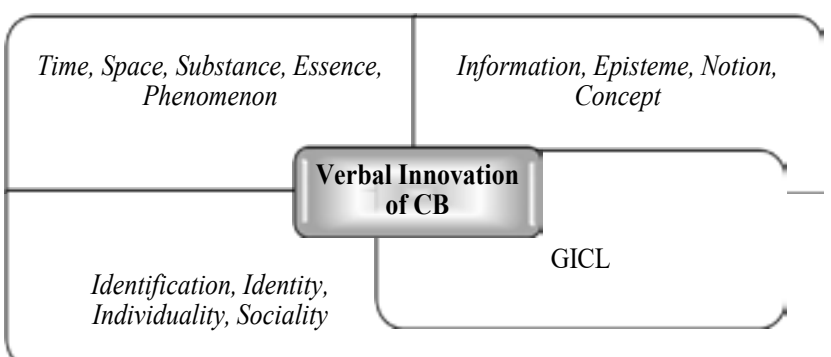

Figure 2. Macrostructure Integativity of GICL

Thus, macrostructure of GICL is defined within this study as comprehensive language body of neologisms in the system of reference semantic unity in correlation with substantive (ontological, epistemic, anthropological) measurements and computer being elements of comprehensive, innovative super-dense verbalization which determines the phenomenological originality of logosphere.

Methodological foundations of the study of Global innovative computer logosphere as an integrated macro-and micro-language object are determined by:

- Firstly: by substantive definite features of logosphere as a macrostructure (including equifinality - ability to achieve conditions that do not depend on the initial conditions and specific parameters that are defined only Global innovative computer logosphere; teleology - gnostic ability of innovative computer being logosphere to achieve the projected state);

- Secondly: by phenomenological characteristics and properties of linguistic units substrate microstructure of Global innovative computer being logosphere.

Research and configuration cross-integration of macro and microstructure of Global innovative computer logosphere is based on the following initial presupposition:

I. Presumption of a conceptual nucleus in the content plane of the logosphere of modern European and Oriental languages realm in general. The conceptual core of Global logosphere is a universal meaningful construct, concentration of content elements mediated by subjective and collective cognitive experience of native language speakers.

Note that the partial correlates of appointed terminological concepts can be the nominated "world view", "conceptual world view", "conceptual model of the world" - [18; 20; 27]; differential features category "conceptual nucleus" within this study is determined by configurative cumulativeness of components in the appropriate content area.

Based on genus-species characteristics of parametric notion of "conceptual world view" and its derivatives poly-lateral, conceptual core of the logosphere is understood as a universal semantic construct concentrate of semantic elements mediated by individual and collective cognitive experiences of native speakers. Semantic elements of the conceptual core of the logosphere (based on methodological angles defining concepts and conceptual structures that are conventional in modern cognitive linguistics) are explicated by establishing conceptual attributes (the term after M.V. Pimenov) - that are ambivalently understood as: a) construal elements of conceptual structures; b) substrate conceptual structures. The differential feature of the notion of "conceptual nucleus of logosphere" is the configurative cumulativeness of components that are parameterized in different types of planes of reality mapping, the relevant semantic field.
II. Presumption of the conceptual core projection of Global logosphere substantial layer onto sectoral innovation logosphere of modern European and Oriental languages in general (respectively - a substantial layer of the Global innovative computer logosphere, in particular).

Accordingly, in the projection of the conceptual nucleus of the Global innovative computer logosphere are the concentrate content elements mediated by subjective and collective cognitive experience of European and Oriental languages speakers in the area of interaction and use of digital technologies, which is a proportional and adequate "fingerprint" concentrate of content elements mediated by subjective and collective cognitive experiences of globalized languages speakers in general.

III. Ongoing diffusion process of conceptual projection nucleus on the Global innovative computer logosphere, which resulted in the structure of the internal form units microstructure of Global innovative computer logosphere to be dominated by substance elements.

Thus, the dynamics of Global innovative computer logosphere are ways, directions and appropriate language implementation mechanisms of qualitative changes in the content area of the projection of the conceptual nucleus of the Global innovative logosphere. Empirical identification of defined parameters of GICL dynamics is made possible due to the typological characteristics of the microstructure of Global innovative computer logosphere units - Innovative computer terminus (term-logos) of ICT.

The structure of the content of the innovative computer terminos in European and Oriental languages alike is distributed in the following sabers, and is consistent through a vertical ratio which satisfies the dialectical categories of "essence" $\rightarrow$ "phenomenon":

1) - ontological denotatum (OD) - a set of meaningful elements of exhaustive degree of substance and epistemic abstraction (phenomenalogization attributes, parameters and properties of elements multi-substrat computer being) in the structure of meaning of an innovative computer terminos $\rightarrow 2$ ) - conceptual denotatum (CD) - a set of meaningful elements of median level of abstraction mediated by anthropogenic (subjective and collective) cognitive experiences of European and Oriental languages speakers in the area of interaction and use of computer technology, the projection area of GICL conceptual nucleus $\rightarrow 3$ ) - lingual denotatum (LD) - semantics of innovative computer terminos.

The degree of abstraction of these sabers structure of the content of the innovative computer terminos correlates with the degree of abstraction of ICTs parametric features. Saber (1) "ontological denotatum" corresponds to the parametric feature "existential dimension", saber (2) "conceptual denotatum" to the parametric feature "notion" and the parametric feature "concept"; saber (3) "lingual denotatum" - to the parametric feature of a "language unit".

Instrumental apparatus of algorithmic procedures for conceptual analysis (which usually involves component analysis of the content of a linguistic unit) permits to identify elements of implicit lingual meanings that serve as "access points" (the term by R. Langacker) to the content structure of the content. However, off-grid of the component and, more broadly, the underlying conceptual analysis are the essential (substant) elements that parameterize the structure of the content of ICTs as phenomenological correlates of digital components of being. These elements form the basis of onthological denotatum of ICTs. 
Given the specific characteristics of the Global innovation computer logosphere the identification onthological denotata in the structure of the content of ICTs discloses typological peculiarity ICTs as the specific nature of the sign.

The meaningfuly discrete unit of ontological denotatum for innovative computer terminos is perceived as a substanteme - the in-depth and essential element of the content substance of a computer verbal innovation that is identified both deductively and inductively. Deductive identification is by layering phenomenological diagnosis $[13 ; 17$; 26] of the content elements of the GICL microstructure parallel phenomenological reduction and content of computer elements to the definition of being "phenomenological points of intersection" - isomorphic or correlative content substant components. Inductively substanteme is identified through procedural component analysis and correlation of multi-level conceptual structures of the ICTs content.

The accordance of the dialectical nature of consistent level structure of the ICTs content within dialectical opposition "entity/ phenomenon", where step (1) "ontological denotatum" corresponds to the dialectical category of "essence", step (3) "lingual denotatum" - to the dialectical category of "phenomenon", discrete elements of saber (3) of the ICTs content (seme) and discrete elements saber (1) of the ICTs content (substanteme) typology is correlated in isomorphic manner.

Given the synchronous rate and a significant degree of phenomenological density of lingual representation of multi-substrat elements of computer being, all levels of the structure of the ICTs content (and partially - the expression) in modern globalized European and Oriental languages store signs of an extensional (term after R. Carnap), and therefore may be considered denotative by their phenomenological nature.

The degree of abstraction of these sabers structure of the content of the innovative computer terminos correlates with the degree of abstraction of ICTs parametric features (see figure 3):

Accordingly, the level (1\%/1) - "ontological denotatum" - corresponds to parametric feature "existential dimension" (substanteme), level (2) "conceptual denotatum" - to the parametric features "concept" and "concept" stage $\left(3^{0} / 3\right)$ "lingual denotatum" - to the parametric sign "language units" (terminos).

For example, equivalent ICT born digital, digital natives in European and Oriental languages phenomenological structure is disclosed in the following stratified way: (Jap.)

born digital(Eng.) / nacido-digital (Esp.) / デジタル生まれ

- (1) Substance (OD): TECHNOGENESIS $\rightarrow$ Concept (CD) (2) OBJECT OF COMPUTER BEING $\rightarrow$ Meaning (LD) (3) of the computer object being that is immanent element computer substance of life.

- (1) Substance (OD): TECHNOMORPHISM $\rightarrow$ Concept (CD) (2) SUBJECT OF COMPUTER BEING $\rightarrow$ Meaning (LD) (3) the subject of computer being born and raised within substantive (chronological) timeframe of outside the computer.

digital native (Eng.) / nativo digital (Esp.) / デジタル・ネイ ティブ (Jap.)

- Substance (OD): TECHNOGENESIS $\rightarrow$ Concept (CD) (2) SUBJECT OF COMPUTER BEING $\rightarrow$ Meaning (LD) (3) a person born or brought up during the age of digital technology and therefore familiar with computers and the internet from an early age.

As can be seen from the scheme, the compliance of correlative levels $1^{0}-3^{0}$ in the structure of ICTs content demonstrates phenomenological status verification of an innovative lingual unit. Note that in the proposed scheme correlative substance and lingual surfaces of ICTs acquire a kind of phenomenological constants.

Conclusions. The macrostructure of the Global innovative logosphere of computer being is the generality of linguistic innovations of globalized European and Oriental languages in the systemic semantic unity of their reference correlation with the substantive (ontological, epistemic, anthropological) dimensions and elements of $\mathrm{CB}$. The integration of the macro level of the global innovative logosphere of the $\mathrm{CB}$ is coordinated by the spectrum of its specific characteristics and is realized, first, due to the significant coordination of elements of internal and external form of this logosphere and signs of substantive and substrate originality of computer being as a whole; secondly, due to the phenomenological correlation of the elements of the internal and external form of the innovative computer logosphere and various types of structural elements of the computer being (ontological, epistemic and anthropological respectively), exhaustive, super-dense innovative verbalization of which determines the differential specificity of the studied logosphere.

The microstructure of Global innovative computer logosphere is formed by the generality of discrete language units of the corresponding reference affiliation in the set of their formative and semantic features. The integration of the innovative logosphere CB is ensured by the configurative isomorphism of taxonymic (ontological, epistemic, anthropological) and operational mechanisms of integration of the macrostructure of the innovative $\mathrm{CB}$ and taxonymic and operational mechanisms of integration of its external (formative) microstructure. The ontological denotatum in the structure of the ICTs content plane determines the symbolic specificity of the term as an integer of the macro- and micro-level structures of the Global

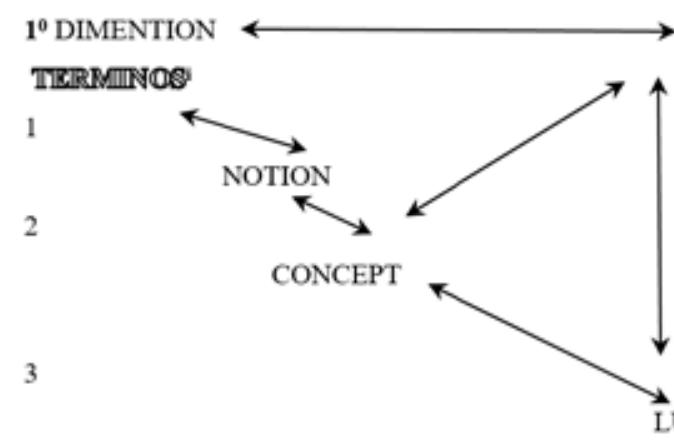

$\mathbb{L} \mathbb{J}^{r}$

A LINGUal Denotatum

$\uparrow$ CONCEPTUAL DENOTATUM

$\uparrow$

ONTHOLOGICAL DENOTATUM

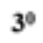

3

2

Figure 3. ICTs Content Microstructure 
innovative computer logosphere. Qualitative and quantitative characteristics, features and properties of the integrative structure of the innovative computer logosphere are informed by its dynamics on the macro and micro levels. The dynamics of the Global innovative computer logosphere is defined as a qualifier of paths, directions and corresponding linguistic-structural mechanisms of realization of qualitative semantic changes in the integrative zone of vertical contraction (cumulation) or divergence (dissipation) of different-level and multisubstrate elements. The operators of the processes of phenomenological mobility of extensional elements of ICTs are transformations of semantic elements (discrete conceptual features and their combinations), which constitute a zone of accumulation of information mediated by individual and collective cognitive experience of globalized European and Oriental languages speakers in the functioning and use of digital technologies.

\section{References:}

1. Allen P. Information culture is in need of development. Network News, 2003. September 19. P. 21-22.

2. Allison D. Derrida's critique of Husserl and the philosophy of presence. Veritas. 2005. V. 50 (1). P. 89-99.

3. Aristotle, "Categories". In Barnes, Jonathan (ed.). The Complete Works of Aristotle, 2 vols (One-Volume Digital Edition). Transl. J.L. Ackrill. Princeton : Princeton University Press., 2014. P. 2510.

4. Bell D. Social Framework of the Information Society. Oxford : Oxford U. Press, 1987. 315 p.

5. Budko V. Adekvatnost' nauchnogo poznanija. Har'kov : Logos, 1990. $154 \mathrm{p}$.

6. Gachev G., Gumanitarnyj kommentarij k estestvoznaniju, Voprosy Literatury. Issue 11. 1993. P. 71-78.

7. Gelernter D. Virtual Realism. Oxford: Oxford University Press, 1998. $138 \mathrm{p}$.

8. Heim M. The Metaphysics of Virtual Reality. LA: Westport Publishers, 1993.

9. Kasavin I. Postigaja mnogoobrazie razuma. Zabluzhdajushhijsja razum? Mnogoobrazie Vnenauchnogo Znanija. Moscow, 1990. P. 67-79.

10. Kireev G. O kartine mira. Kosmologicheskoe esse. Lebed‘. Issue 534. 2008. P. 25-29.

11. Makhachashvili R. Models and Digital Diagnostics Tools for the Innovative Polylingual Logosphere of Computer Being Dynamics. Italian-Ukrainian Contrastive Studies: Linguistics, Literature, Translation : monograph. Peter Lang GmbH Internationaler Verlag der Wissenschaften, Berlin, 2020. P. 99-124.

12. Makhachashvili R. Semenist I. ICT thesaurus modelling recommendations (based on innovations of European and Oriental languages). Studia Filologiczne, 7. 2020. P. 117-128.

13. Zahavi D. Husserl's Phenomenology. Palo Alto : Stanford University Press, 2003. 312 p.

14. Абдеев Р.Ф. Философия информационной цивилизации. Москва : Владос, 1994. $336 \mathrm{c}$.

15. Алексеева И.Ю. Человеческое знание и его компьютерный образ. Москва : Ифран, 1993. $182 \mathrm{c.}$

16. Бабушкин В.У. Феноменологическая философия науки - критический анализ. Москва : Наука, 1985. 246 с.

17. Ингарден Р. Введение в феноменологию Эдмунда Гуссерля. Дом интеллектуальной книги, 1999. 267 с.

18. Карасик В.И., Слышкин Г.Г. Лингвокультурный концепт как единица исследования. Методологические проблемы когнитивной лингвистики. Воронеж : ВГУ, 2001. С. 75-80.

19. Карась А. Реальність і філософія: спроба семіотичного підходу. Філософія науки : збірник наукових статей Львівсько-Варшавського семінару «Філософія науки». Львів, 2006. С. 134-149.
20. Кубрякова Е.С. Об установках когнитивной науки и актуальных проблемах когнитивной лингвистики. Вопросы когнитивной лингвистики. 2004. № 1. С. 6-17.

21. Кутырев В.А. Культура и технология: борьба миров. Москва, Прогресс-Традиция, 2001. 336 с.

22. Кутырев В.А. Пост-пред-гипер-контр-модернизм: концы и начала. Вопросы философии. 1998. № 5. С. 35-41.

23. Лиотар Ж.-Ф. Феноменология. Санкт-Петербург : Алетейя, 2001. $152 \mathrm{c}$.

24. Лосев А.Ф. Философия имени. Бытие. Имя. Космос. Москва : Мысль, 1993. С. 613-801.

25. Мамардашвили М.К., Пятигорский А.М. Символ и сознание. Метафизические рассуждения о сознании, символике и языке. Москва : Школа «Языки русской культуры», 1997. 216 с.

26. Мерло-Понти М. Феноменологія сприйняття. Київ : Український Центр духовної культури, 2001. 552 с

27. Никитин М. Развернутые тезисы о концептах. Вопросы когнитивной лингвистики. 2004. № 1. С. 53-64.

Махачашвілі Р. К., Семеніст І. В. Онтологічні площі глобальної інноваційної логосфери структури комп'ютерів (на основі свропейських і східних мов)

Анотація. Статтю присвячено онтологічним передумовам всебічного структурування глобальної інноваційної лінгвістичної сфери сучасних цифрових технологій (Глобальна інноваційна логосфера комп'ютера будується трансформативними неологічними шарами сучасних європейських та східних мов міжнародного спілкування). Макроструктура глобальної інноваційної логосфери комп'ютерного буття визначається як сукупність мовних інновацій глобалізованих європейських та східних мов у системній семантичній єдності їх референтного співвідношення із сутнісними (онтологічними, епістемічними, антропологічними) вимірами та елементами комп'ютерної реальності. Інтеграція макрорівня глобальної інноваційної комп'ютерної логосфери координується спектром іiі специфічних характеристик і реалізується, по-перше, завдяки значній координації елементів внутрішньої та зовнішньої форми цієї логосфери та ознак предметної та субстратної оригінальності комп'ютерного буття як єдиного цілого; по-друге, завдяки феноменологічному співвідношенню елементів внутрішньої та зовнішньої форми інноваційної комп'ютерної логосфери та різним типам структурних елементів комп'ютерного буття (онтологічних, епістемічних та антропологічних відповідно), вичерпна надщільна інноваційна вербалізація яких визначає диференціальну специфіку досліджуваної логосфери. Мікроструктура глобальної інноваційної комп'ютерної логосфери формується загальністю дискретних мовних одиниць відповідної референтної належності за сукупністю їхніх формотворчих та змістових ознак. Інтеграція інноваційної комп'ютерної логосфери забезпечується конфігуративним ізоморфізмом таксономічних (онтологічних, епістемічних, антропологічних) та операційних механізмів інтеграції макроструктури інноваційного комп'ютерного буття та таксономічних та операційних механізмів інтеграції її зовнішньої (формотворчої) мікроструктури. Онтологічний денотат у структурі площини змісту IКТ визначає символічну специфіку терміна як єдності макро- та мікрорівневих структур Глобальної інноваційної комп'ютерної логосфери. Якісні та кількісні характеристики, особливості та властивості інтегративної структури інноваційної комп'ютерної логосфери визначаються її динамікою на макро- та мікрорівнях.

Ключові слова: глобальна інноваційна логосфера, комп'ютерне буття, інноваційний комп'ютерний термінос, європейські мови, східні мови. 